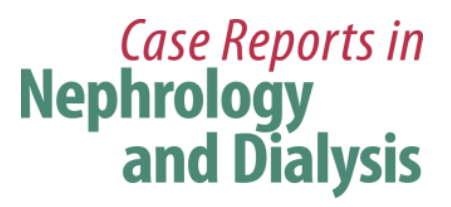

Case Rep Nephrol Dial 2018;8:62-69

DOI: 10.1159/000487921

Publisned online: Vvarch 28, 2018

(c) 2018 The Author(s)

Published by S. Karger AG, Basel

www.karger.com/cnd

This article is licensed under the Creative Commons Attribution-NonCommercial 4.0 International License (CC BY-NC) (http://www.karger.com/Services/OpenAccessLicense). Usage and distribution for commercial purposes requires written permission.

\title{
Tolvaptan for Primary Aldosteronism and Autosomal Dominant Polycystic Kidney Disease: A Case Report
}

Kyohei Kunizawa $^{a}$ Junichi Hoshino ${ }^{a}$ Hiroki Mizuno $^{a} \quad$ Tatsuya Suwabe $^{a}$ Keiichi Sumida $^{a}$ Masahiro Kawada ${ }^{a}$ Masayuki Yamanouchi ${ }^{a}$ Akinari Sekine $^{a} \quad$ Noriko Hayami $^{a}$ Rikako Hiramatsu ${ }^{a}$ Eiko Hasegawa ${ }^{a}$ Naoki Sawa ${ }^{a}$ Kenmei Takaichi ${ }^{a, b}$ Shigeru Shibata ${ }^{c}$ Yoshifumi Ubara ${ }^{a} b$

${ }^{a}$ Nephrology Center, Toranomon Hospital Kajigaya, Kawasaki, Japan; ${ }^{b}$ Okinaka Memorial Institute for Medical Research, Toranomon Hospital Kajigaya, Kawasaki, Japan; 'Division of Nephrology, Department of Internal Medicine, Teikyo University School of Medicine, Tokyo, Japan

\section{Keywords}

Tolvaptan $\cdot$ Autosomal dominant polycystic kidney disease $\cdot$ Primary aldosteronism

\section{Abstract}

A 59-year-old Japanese woman was admitted for evaluation of muscle weakness. Autosomal dominant polycystic kidney disease had been diagnosed at the age of 47 years, followed by primary aldosteronism at 53 years. At the age of 58 , tolvaptan was started (60 mg/day) to treat her renal disease. After 8 months of tolvaptan therapy, hypokalemia-related muscle weakness became prominent, and hypertension became refractory. Finally, treatment with low-dose tolvaptan (30 mg/day) and high-dose spironolactone (100 mg/day) normalized 


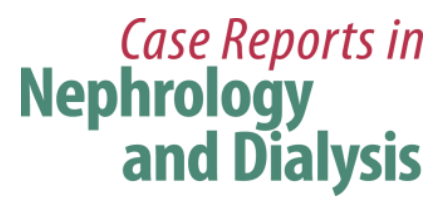

Case Rep Nephrol Dial 2018;8:62-69

DOI: $10.1159 / 00048792$

(c) 2018 The Author(s). Published by S. Karger AG, Basel www.karger.com/cnd

Kunizawa et al.: Tolvaptan for Primary Aldosteronism and Autosomal Dominant Polycystic Kidney Disease: A Case Report

serum potassium and the blood pressure. Tolvaptan can induce urinary excretion of potassium in patients with primary aldosteronism, and possible mechanisms are discussed.

(C) 2018 The Author(s)

Published by S. Karger AG, Basel

\section{Introduction}

Torres et al. [1] reported that tolvaptan (a vasopressin V2 receptor antagonist) slowed the increase of the total kidney volume and decline of renal function over a 3-year period in patients with autosomal dominant polycystic kidney disease (ADPKD) compared to placebo. In addition, Muto et al. [2] reported that tolvaptan was effective in 118 Japanese patients with ADPKD, since it reduced the annual growth rate of total kidney volume and slowed the decline of kidney function over 36 months. Tolvaptan was approved as an option for the medical treatment of ADPKD patients in Japan. In the above 2 studies, hypokalemia was not noted as a serious complication. We treated a 59-year-old Japanese woman with ADPKD and primary aldosteronism. Eight months after starting tolvaptan therapy, she developed definite hypokalemia-related muscle weakness, and her hypertension became refractory. The influence of tolvaptan on potassium metabolism in this patient is discussed.

\section{Case Report}

A 59-year-old Japanese woman was admitted to our hospital for evaluation of muscle weakness. Hypertension had been detected at the age of 30 years. When she was 47, ADPKD was diagnosed because computed tomography showed polycystic kidneys and her father had this disease. At 53 years, primary aldosteronism was diagnosed after detection of hypokalemia and a left adrenal tumor. Spironolactone was administered. An angiotensin II receptor blocker (ARB; olmesartan at $40 \mathrm{mg} /$ day) was added to treat hypertension, after which her blood pressure and serum potassium level were normalized despite discontinuation of spironolactone (Table 1). At 58 years, tolvaptan therapy was started at $60 \mathrm{mg} /$ day (morning and afternoon doses of 45 and $15 \mathrm{mg}$ ) to treat her renal disease (Table 1; Fig. 1). Hypertension became more severe after the initiation of tolvaptan. Although the dual action beta blocker/alpha-1 blocker carvedilol (15 mg/day), calcium channel blocker cilnidipine (20 mg/day), and ARB telmisartan (40 mg/day) were added, her hypertension was not controlled. Eight months after starting tolvaptan, muscle weakness and numbness of the lower limbs became problematic. At 12 months, she was admitted to our hospital.

On admission, the patient was $152 \mathrm{~cm}$ tall, weighed $61 \mathrm{~kg}$, and had a blood pressure of 182/84 mm Hg. Laboratory tests revealed that serum creatinine was $1.1 \mathrm{mg} / \mathrm{dL}$ (eGFR: 39.7 $\mathrm{mL} / \mathrm{min} / 1.73 \mathrm{~m}^{2}$ ), urea nitrogen was $24 \mathrm{mg} / \mathrm{dL}$, Na was $144 \mathrm{mmol} / \mathrm{L}, \mathrm{K}$ was $2.5 \mathrm{mmol} / \mathrm{L}$, and $\mathrm{Cl}$ was $99 \mathrm{mmol} / \mathrm{L}$. Renin activity was $<0.2 \mathrm{ng} / \mathrm{mL} / \mathrm{h}$ (normal: $0.3-2.3$ ), and the aldosterone concentration was $130 \mathrm{ng} / \mathrm{dL}$ (normal: 3.0-15.0). Urinary $\mathrm{K}$ excretion was 65 $\mathrm{mmol} /$ day, $\mathrm{Na}$ excretion was $130 \mathrm{mmol} /$ day, and $\mathrm{Cl}$ excretion was $120 \mathrm{mmol} /$ day (Table 1). 


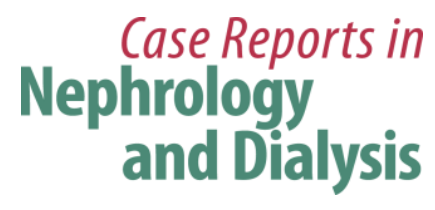

Case Rep Nephrol Dial 2018;8:62-69

DOI: $10.1159 / 00048792$

(c) 2018 The Author(s). Published by S. Karger AG, Base www.karger.com/cnd

Kunizawa et al.: Tolvaptan for Primary Aldosteronism and Autosomal Dominant

Polycystic Kidney Disease: A Case Report

\section{Clinical Course}

Before admission, hypokalemia was exacerbated after starting tolvaptan therapy, and her hypertension became refractory (Fig. 2). The patient hoped to continue tolvaptan use. Therefore, a potassium supplement was administered, but her serum potassium only increased to $3.5 \mathrm{mmol} / \mathrm{L}$. Tolvaptan was discontinued temporarily, and serum potassium increased to $4.0 \mathrm{mmol} / \mathrm{L}$. Next, tolvaptan $(60 \mathrm{mg} /$ day $)$ and spironolactone $(50 \mathrm{mg} /$ day $)$ were administered concomitantly, but the serum potassium level dropped to $3.0 \mathrm{mmol} / \mathrm{L}$. Subsequently, tolvaptan was tapered to a daily dose of $30 \mathrm{mg}$, and spironolactone was increased to a daily dose of $100 \mathrm{mg}$. Thereafter, serum potassium remained above $4.0 \mathrm{mmol} / \mathrm{L}$, and control of the blood pressure improved.

\section{Discussion}

In this patient, hypokalemia and hypertension related to primary aldosteronism were initially controlled by spironolactone and then by an ARB alone, even after spironolactone had been discontinued. Hypokalemia became more pronounced after the patient started tolvaptan therapy, probably due to excessive excretion of potassium, and could not be corrected by administration of a potassium supplement. Discontinuation of tolvaptan led to normalization of serum potassium and better control of hypertension. Finally, treatment with low-dose tolvaptan (30 mg/day) and high-dose spironolactone (100 mg/day) achieved normalization of serum potassium as well as blood pressure. The mechanism of hypokalemia in this patient after administration of tolvaptan is interesting.

Torres et al. [1] investigated the effects of tolvaptan in 961 patients participating in the ADPKD TEMPO 3:4 clinical trials. Hypokalemia was not reported as an adverse effect, although hypernatremia was considered to require attention. Kim et al. [3] reported on the pharmacokinetics, pharmacodynamics, and safety of tolvaptan in healthy Japanese subjects. They stated that the serum sodium concentration was increased by tolvaptan and was higher than with placebo, even $24 \mathrm{~h}$ after dosing, while serum potassium was unchanged. These studies indicate that tolvaptan does not affect potassium metabolism, even though urinary water and sodium excretion is affected by higher doses of tolvaptan.

In our patient, serum and urinary $\mathrm{K}$ levels at the time of admission were $2.5 \mathrm{mmol} / \mathrm{L}$ and $65 \mathrm{mmol} /$ day, respectively, indicating the urinary K loss as a cause of hypokalemia. Although tolvaptan alone did not alter urinary K excretion (as stated above) it may have affected aldosterone secretion and/or aldosterone signaling in the kidney. Concomitant progression of hypokalemia and hypertension after tolvaptan treatment in the presented case supports the possibility [4]. Moreover, discontinuation of tolvaptan ameliorated hypokalemia (Fig. 2). As for the role of vasopressin in the adrenal gland, previous studies have shown that vasopressin V1a receptor is present in the adrenal cortex, where it regulates adrenal hormone secretion. More interestingly, vasopressin (but not desmopressin) increased aldosterone secretion in a patient with aldosterone-producing adenoma, which is likely due to aberrant receptor signaling in the adenoma [5]. Given the evidence, it may be that a high-dose tolvaptan treatment elevated plasma ADH levels, which may have promoted aldosterone secretion in the tumor through V1 receptor signaling. Unfortunately, however, the temporal profile of plasma renin and aldosterone levels is not available. In addition to this mechanism, inhibi- 


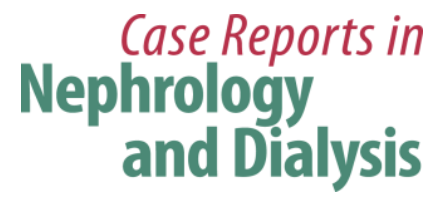

Case Rep Nephrol Dial 2018;8:62-69

(c) 2018 The Author(s). Published by S. Karger AG, Basel www.karger.com/cnd

Kunizawa et al.: Tolvaptan for Primary Aldosteronism and Autosomal Dominant Polycystic Kidney Disease: A Case Report

tion of Na-Cl cotransporter (NCC) activity may have contributed to the occurrence of severe hypokalemia. Insights from recent studies suggest that NCC activation counteracts the progressive decrease in plasma $\mathrm{K}$ levels in primary aldosteronism [6]. Because several studies have suggested that the angiotensin II and also vasopressin V2 receptor pathways increase NCC activity independently of aldosterone [7, 8], the administration of high-dose ARB and tolvaptan may have acted to reduce NCC, which permitted the urinary K loss and occurrence of severe hypokalemia by increasing distal Na delivery. Polyuria and increased activity of flow-induced $\mathrm{K}$ secretion might also need to be considered. Although mechanisms are not entirely clear, the present case clearly illustrates that $\mathrm{V} 2$ receptor antagonism can modulate aldosterone signaling and worsen the clinical course of primary aldosteronism.

In conclusion, tolvaptan does not normally influence potassium regulation. However, in patients with primary aldosteronism, tolvaptan can induce urinary excretion of potassium. Although the mechanisms need further investigation, aberrant V1 receptor signaling in the adrenal gland and also the modulation of NCC activity in the kidney may play a role, leading to hypokalemia and refractory hypertension. In our patient with primary aldosterone and ADPKD, addition of spironolactone allowed continuation of tolvaptan therapy by stimulating NCC activity.

\section{Acknowledgment}

This study was funded by the Okinaka Memorial Institute for Medical Research.

\section{Statement of Ethics}

Informed consent was obtained from all individual participants included in the study. This article does not contain any studies with human participants performed by any of the authors.

\section{Disclosures Statement}

The authors declare that they have no conflicts of interest to disclose.

\section{References}

1 Torres VE, Chapman AB, Devuyst 0, et al: Tolvaptan in patients with autosomal dominant polycystic kidney disease. N Engl J Med 2012;367:2407-2418.

2 Muto S, Kawano H, Higashihara E, et al: The effect of tolvaptan on autosomal dominant polycystic kidney disease patients: a subgroup analysis of the Japanese patient subset from TEMPO 3:4 trial. Clin Exp Nephrol 2015;19:867-877. 
3 Kim SR, Hasunuma T, Sato 0, Okada T, Kondo M, Azuma J: Pharmacokinetics, pharmacodynamics and safety of tolvaptan, a novel, oral, selective nonpeptide AVP V2-receptor antagonist: results of singleand multiple-dose studies in healthy Japanese male volunteers. Cardiovasc Drugs Ther 2011;25(suppl 1):S5-S17.

4 Grazzini E, Boccara G, Joubert D, Trueba M, Durroux T, Guillon G, Gallo-Payet N, Chouinard L, Payet MD, Serradeil Le Gal C: Vasopressin regulates adrenal functions by acting through different vasopressin receptor subtypes. Adv Exp Med Biol 1998;449:325-334.

5 Dateki S, Kosaka K, Hasegawa K, Tanaka H, Azuma N, Yokoya S, Muroya K, Adachi M, Tajima T, Motomura K, Kinoshita E, Moriuchi H, Sato N, Fukami M, Ogata T: Heterozygous orthodenticle homeobox 2 mutations are associated with variable pituitary phenotype. J Clin Endocrinol Metab 2010;95:756-764.

Ellison DH, Terker AS, Gamba G: Potassium and its discontents: new insight, new treatments. J Am Soc Nephrol 2016;27:981-989.

7 Saritas T, Borschewski A, McCormick JA, Paliege A, Dathe C, Uchida S, Terker A, Himmerkus N, Bleich M, Demaretz S, Laghmani K, Delpire E, Ellison DH, Bachmann S, Mutig K: SPAK differentially mediates vasopressin effects on sodium cotransporters. J Am Soc Nephrol 2013;24:407-418. Shibata S, Arroyo JP, Castañeda-Bueno M, Puthumana J, Zhang J, Uchida S, Stone KL, Lam TT, Lifton RP: Angiotensin II signaling via protein kinase C phosphorylates Kelch-like 3, preventing WNK4 degradation. Proc Natl Acad Sci USA 2014;111:15556-15561. 
Case Reports in Nephrology and Dialysis
Case Rep Nephrol Dial 2018;8:62-69

DOI: $10.1159 / 00048792$

(C)

(C) 2018 The Author(s). Published by S. Karger AG, Basel www.karger.com/cnd

Kunizawa et al.: Tolvaptan for Primary Aldosteronism and Autosomal Dominant

Polycystic Kidney Disease: A Case Report

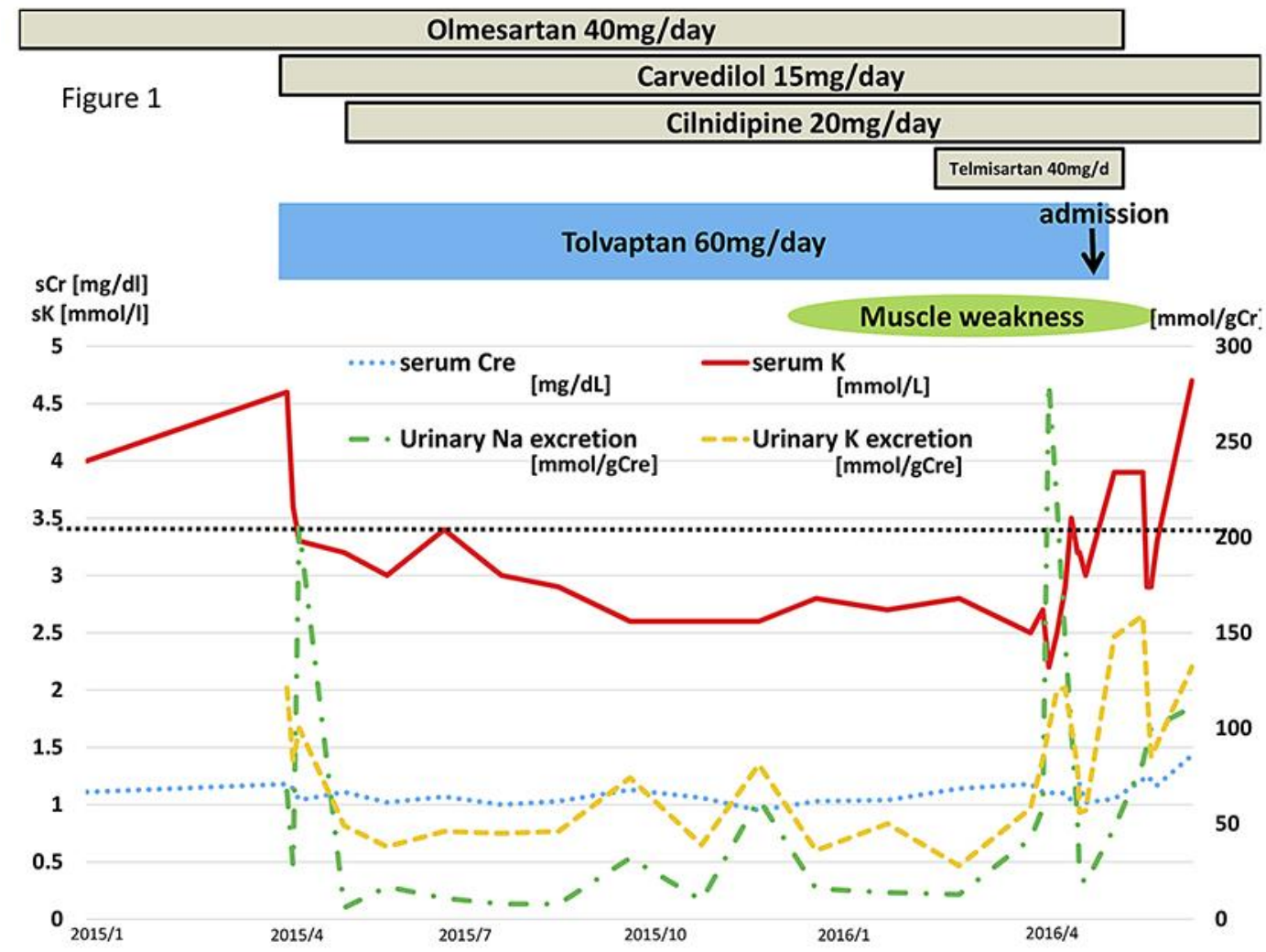

Fig. 1. Clinical course part 1: the clinical course before admission. 


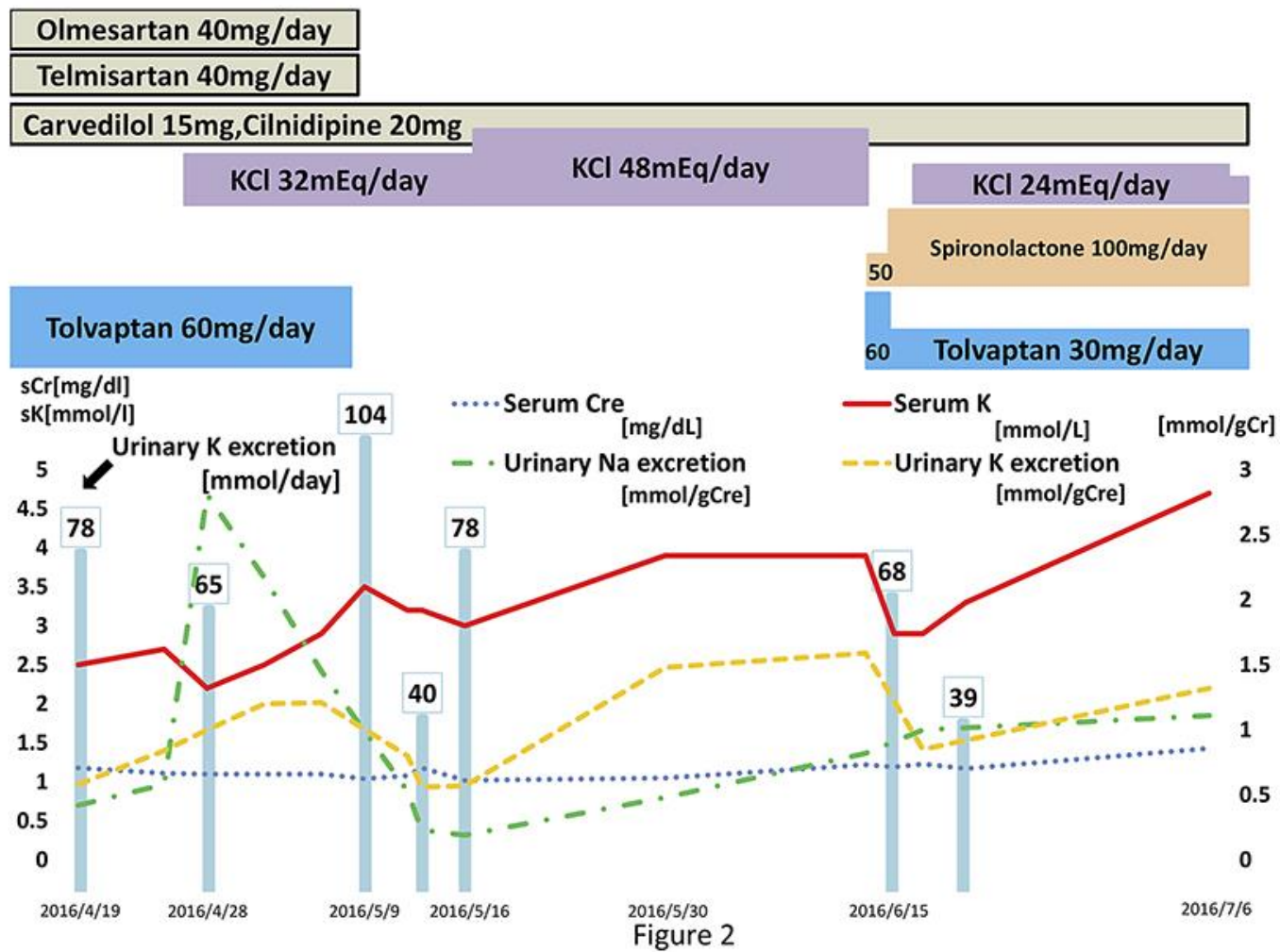

Fig. 2. Clinical course part 2: the clinical course after admission. 


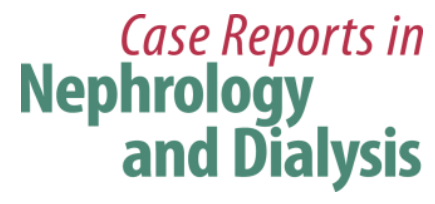

\begin{tabular}{l|l}
\hline Case Rep Nephrol Dial 2018;8:62-69 \\
\hline DOI: 10.1159/000487921 & $\begin{array}{l}\text { (c) } 2018 \text { The Author(s). Published by S. Karger AG, Basel } \\
\text { www.karger.com/cnd }\end{array}$
\end{tabular}

Kunizawa et al.: Tolvaptan for Primary Aldosteronism and Autosomal Dominant

Polycystic Kidney Disease: A Case Report

Table 1. Patient data before therapy and after 12 months

\begin{tabular}{|c|c|c|c|c|c|c|c|}
\hline & Before & $\begin{array}{l}\text { After } \\
12 \text { months }\end{array}$ & $\begin{array}{l}\text { Normal } \\
\text { range }\end{array}$ & & Before & $\begin{array}{l}\text { After } \\
12 \text { months }\end{array}$ & $\begin{array}{l}\text { Normal } \\
\text { range }\end{array}$ \\
\hline White blood cell, $/ \mu \mathrm{L}$ & 4,700 & 6,700 & $3,400-9,200$ & $\mathrm{CRP}, \mathrm{mg} / \mathrm{dL}$ & 7.1 & 0.1 & $0.0-0.3$ \\
\hline Red blood cell, $\times 10^{4} / \mu \mathrm{L}$ & 406 & 402 & $400-566$ & & & & \\
\hline Hemoglobin, g/dL & 13.5 & 12,7 & $13.0-17.0$ & Urinalysis & & & \\
\hline Hematocrit, \% & 39.4 & 36.8 & $38.2-50.8$ & Glucose & Negative & Negative & Negative \\
\hline Platelet, $\times 10^{4} / \mu \mathrm{L}$ & 13.7 & 16 & $14.1-32.7$ & Sediment & & & \\
\hline Total protein, g/dL & 7.1 & 7,3 & $6.9-8.4$ & RBC, /HPF & $>100$ & $1-4$ & $<1$ \\
\hline Albumin, g/dl & 3.9 & 3.8 & $3.9-5.2$ & WBC, /HPF & $1-4$ & $<1$ & $<1$ \\
\hline Total bilirubin, $\mathrm{mg} / \mathrm{dL}$ & 0.5 & 0.6 & $0.3-1.1$ & Cast & None & None & $<1$ \\
\hline AST, IU/L & 20 & 24 & $13-33$ & Protein, g/day & 0.3 & 2.6 & \\
\hline ALT, IU/L & 14 & 16 & $8-42$ & NAG, IU/day & 4.3 & 15.1 & $0.8-5.0$ \\
\hline LDH, IU/L & 221 & 302 & $119-229$ & $\alpha 1 \mathrm{MG}, \mathrm{mg} /$ day & 3.8 & 12.9 & $0.6-8.8$ \\
\hline CPK, IU/L & 95 & 193 & $62-287$ & $\beta 2 \mathrm{MG}, \mu \mathrm{g} /$ day & 1 & 11.1 & $0.1-1.9$ \\
\hline ALP, IU/L & 185 & 214 & $117-350$ & $\mathrm{Na}, \mathrm{mmol} /$ day & 37 & 130 & $40-400$ \\
\hline$\gamma \mathrm{GTP}, \mathrm{IU} / \mathrm{L}$ & 39 & 37 & $9-109$ & $\mathrm{~K}, \mathrm{mmol} /$ day & 33 & 65 & $10-120$ \\
\hline $\mathrm{UN}, \mathrm{mg} / \mathrm{dL}$ & 28 & 24 & $8-12$ & $\mathrm{Cl}, \mathrm{mmol} / \mathrm{d}$ & 73 & 120 & $50-400$ \\
\hline Creatinine, mg/dL & 1.2 & 1.2 & $0.65-1.06$ & $\mathrm{Ca}, \mathrm{mg} /$ day & 50 & 38 & $40-200$ \\
\hline $\mathrm{eGFR}, \mathrm{ml} / \mathrm{min} / 1.73 \mathrm{~m}^{3}$ & 37.3 & 37.1 & $>100$ & $\mathrm{P}, \mathrm{g} /$ day & 0.94 & 0.72 & $0.2-1.0$ \\
\hline Urinary acid, mg/dL & 8.2 & 9.2 & $2.5-7.0$ & Cre, g/day & 2.3 & 2.5 & $0.7-2.5$ \\
\hline $\mathrm{Na}, \mathrm{mmol} / \mathrm{L}$ & 141 & 144 & 139-146 & Renin, ng/mL/h & $<0.2$ & 0.2 & $0.3-2.3$ \\
\hline $\mathrm{K}, \mathrm{mmol} / \mathrm{L}$ & 4.6 & 2.5 & $3.7-4.8$ & Aldosterone, ng/dL & 131 & 138 & $3.0-15.0$ \\
\hline $\mathrm{Cl}, \mathrm{mmol} / \mathrm{L}$ & 105 & 99 & 101-108 & & & & \\
\hline $\mathrm{Ca}, \mathrm{mmol} / \mathrm{L}$ & 9.9 & 9.2 & $8.7-10.1$ & & & & \\
\hline $\mathrm{P}, \mathrm{mmol} / \mathrm{L}$ & 4.4 & 4.3 & $2.8-4.6$ & & & & \\
\hline $\mathrm{CRP}, \mathrm{mg} / \mathrm{dL}$ & 0.3 & 0.4 & $0.0-0.3$ & & & & \\
\hline
\end{tabular}

